\title{
アルカリ土類金属含有ゼオライトによる メタノールからの低級オレフィン合成
}

（1986 年 6 月 30 日 受理）

岡戸秀夫*・庄司一宏・ - 川村吉成** ・ 神徳泰彦***

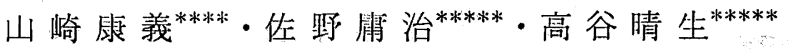

メタノールを原料とする低紙オレフィン合成用触媒として，アルカリ土類金属含有ゼオライトと ZSM-5 ゼオライトを合成した。これらの触媒を用いて常圧流通式反応装置を用いて，400 $600^{\circ} \mathrm{C}$ の範 囲で反応させた。その結果， $\mathrm{Mg}, \mathrm{Ca}, \mathrm{Sr}$ 含有ゼオライト触媒は $500^{\circ} \mathrm{C}$ 以上の高温でも高い活性を示し， エチンンとプロピレンの選択率は最高 $66 \%$ を示したが，ZSM-5 触媒は高温では失活し，Ba 含有ゼオ ライト触媒では低級オンフィンはほとんど生成しなかった。これらの触媒について電子顕微鏡観察， $\mathrm{X}$ 線回折，BET 比表面積測定などを行ない，ゼオライトの結晶形態についての評価を行ならとともに， $\mathrm{NH}_{3}$-TPD 法，拡散反射型 FT-IR 法により酸性質の評洒も行なった。また，反応後触媒について炭素 質の測定も行なった。これらの物性測定により，アルカリ土類金属含有ゼオライト触媒では強酸量が減 少して扣り，平均の酸強度が弱くなっていることが認められた。このことが B.T.X，パラフィン，炭 素質の生成を抑制し，低級オンフィン選択率の向上の原因になっていると推測した。

\section{1 緒言}

メタノールからの低級オレフィン合成に関しては，すでに種々 の方法が報告されている。たとえば i ) 細孔径の小さいゼオライ 卜を用いる方法, ii）反応時の苛酷度を下げる方法, およびiii） 酸性質を制御する方法などが提案されている。また，低級オレフ ィンの合成には，反応温度を高温にするか，またはゼオライト䖵 媒を高シリカ型にすることが有利であることが知られている1)。 メタノールからの低級オレフィン合成は, $5 \sim 8 \mathrm{kcal} / \mathrm{c}-\mathrm{mol}$ の発 熱をともな5反応であるが， $600^{\circ} \mathrm{C}, 1 \mathrm{~atm}$ の反応条件下ではほ ぼ 100\% の炭化水素転化率が得られ，この程度の温度では化学平 衡的な問題はない。

すでに, 著者らは $\mathrm{SiO}_{2} / \mathrm{Al}_{2} \mathrm{O}_{3}$ 比が $70 \sim 3300$ で, 粒子径が 1 $\mu \mathrm{m}$ 以上の ZSM-5 を合成し, $400 \sim 600^{\circ} \mathrm{C}$ でのメタノール転化反 応活性を調べた。その絬果, $500^{\circ} \mathrm{C}$ 以上の高温の反応条件下では, 活性劣化がいちじるしく，とくに高シリカ型卧どいちじるしいこ とを見いだした。また，このいちじるしい活珄劣化が炭絜質の析 出によることを明らかにした2。

本研究では, あらかじめアルカリ土類金属塩を添加して, $\mathrm{SiO}_{2} /$

丸善石油化学株式会社, 104 東京都中央区八丁堀

** 出光石油化学怢式会社, 100 東京都千代田区丸/内

*** 宇部興産株式会社, 100 東京都千代田区霞が関

***** 日本石油化学株式会社, 100 東京都干代田区内幸町

***** 化学技術研究所, 305 㴀城県筑波郡谷田部朾

1) C. D. Chang, C. T-W Chu, R.F. Socha, J. Catal., $86,289(1984)$.

2）岡户秀夫, 庄司宏, 川村吉成, 神德泰彦, 山崎除義, 侁 野海治, 高谷晴生, 日化, 1987, 18.
$\mathrm{Al}_{2} \mathrm{O}_{3}$ 比が 200 のアルカリ土類金属含有ゼオライトを合成し, $400 \sim 600^{\circ} \mathrm{C}$ での人タノルル転化反応を行なったところ, $500^{\circ} \mathrm{C}$ 以上の高温の反応条件下でも活性劣化がなく，低級オレフィンの らち，とくにエチレンとプロピレンの収率の高いゼオライトが見 いだされたので報告する。

\section{2 実験}

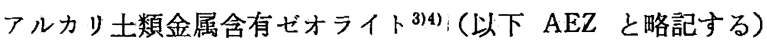
は, 水, テトラプロピルアンモニウムブロミド ( $\mathrm{TPABr}$ ), 水酸 化ナトリウム、アルカリ土類金属酢酸塩, 硝酸アルミニウム・九 水和物, 扣よびシリカ源 (キャタロイド SI-30, 触媒化成製, $\mathrm{SiO}_{2}=30.5 \mathrm{wt} \%, \mathrm{Na}_{2} \mathrm{O}=0.42 \mathrm{wt} \%, \mathrm{H}_{2} \mathrm{O}=69.1 \mathrm{wt} \%$ ）からな る水性ゲル混合物を水熱処理することにより合成した。水性ゲル 混合物の組成は，モル比として以下のと和りである。

$\mathrm{SiO}_{2} / \mathrm{Al}_{2} \mathrm{O}_{3}=200, \mathrm{OH}^{-} / \mathrm{SiO}_{2}=0.1, \quad \mathrm{TPABr} / \mathrm{SiO}_{2}=0.1, \mathrm{H}_{2} \mathrm{O} /$ $\mathrm{SiO}_{2}=40$, アルカリ土類金属酢酸塩 $/ \mathrm{SiO}_{2}=0.025$ 。

ただし、アルカリ土類金属（政）は $\mathrm{Mg}, \mathrm{Ca}, \mathrm{Sr}, \mathrm{Ba}$ である。 また, $\mathrm{OH}^{-} / \mathrm{SiO}_{2}$ 比の算出法, 結晶化条件, 各種物性測定およ びメタノール転化反応条件は，既報 ${ }^{2)}$ と同様である。なお，各生 成物の略号を以下のように定義する。 $\mathrm{C}_{2}{ }^{\prime \prime}=$ エチレン。 $\mathrm{C}_{3}{ }^{\prime \prime}=$ プロ ピレン。 $\mathrm{C}_{4}{ }^{\prime \prime}=\mathrm{C}_{4}$-オレフィン類。 $\mathrm{C}_{5}{ }^{\prime \prime}=\mathrm{C}_{5}$-オレフィン類。 $\mathrm{C}_{2}$ オ $\mathrm{C}_{5}=$ 炭素数 2 5 のパラフィン。 $\mathrm{CH}_{4}=$ ィタン。B.T. $\mathrm{X}=$ ベンゼ ン, トルェン, キシレンの合計。 $\mathrm{C}_{6+}=$ 炭素数 6 以上の炭化水素。

3) H. Okado, K. Hashimoto, K. Kawamura, Y. Yamazaki, H. Takaya, U.S.P. 4, 544, 793(1985).

4）岡戸秀夫, 橋本和生, 川村吉成, 山崎㽷㼁, 高谷晴生, 特 開 昭 59-97523 (1984). 
(a)

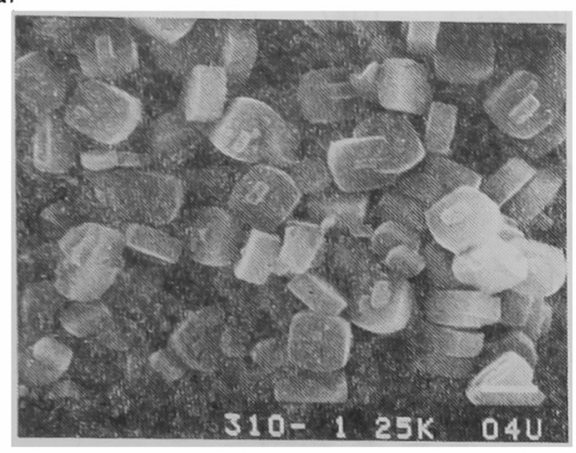

(b)

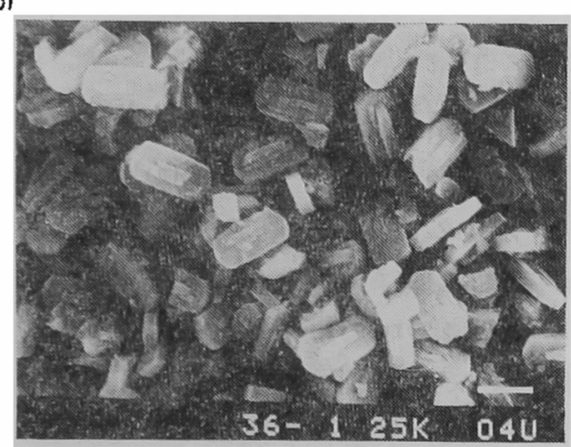

(c)

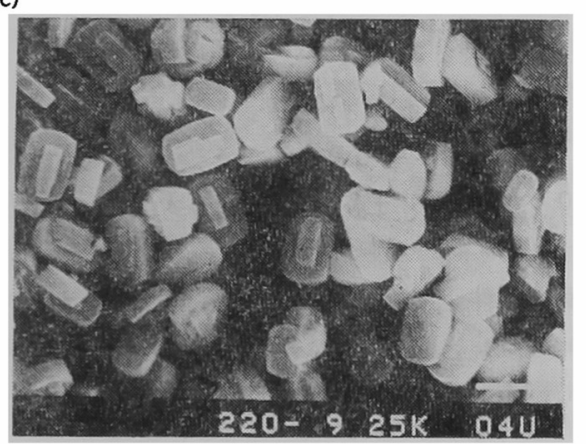

(d)

(a) ZSM-5-200

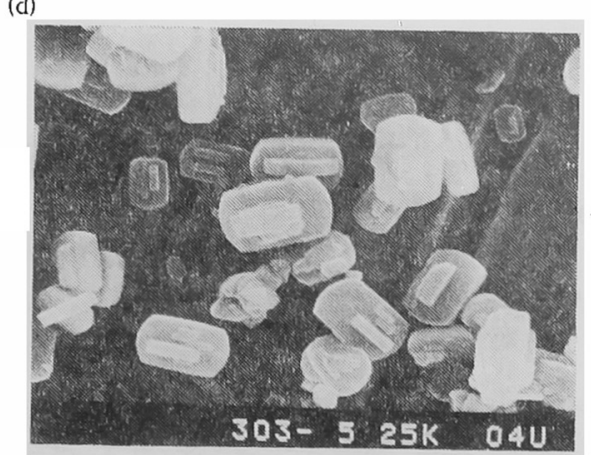

(b)AEZ-Mg-200

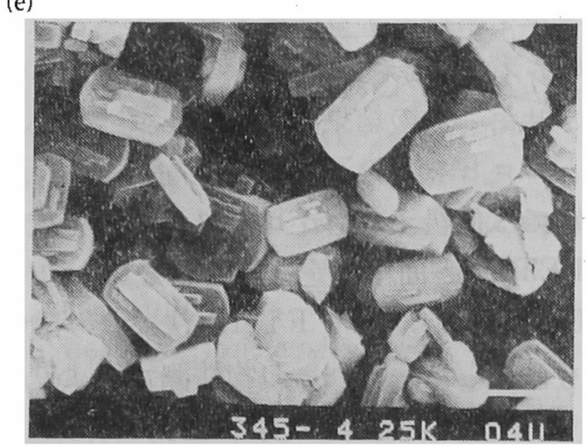

(d)AEZ-Sr-200

(e)AEZ-Ba-200

(c)AEZ-Ca-200

Fig. 1 SEM micrographs of various zeolites

(a) : ZSM-5-200, (b ):AEZ-Mg-200, (c):AEZ-Ca-200, (d ):AEZ-Sr-200, (e) :AEZ-Ba-200

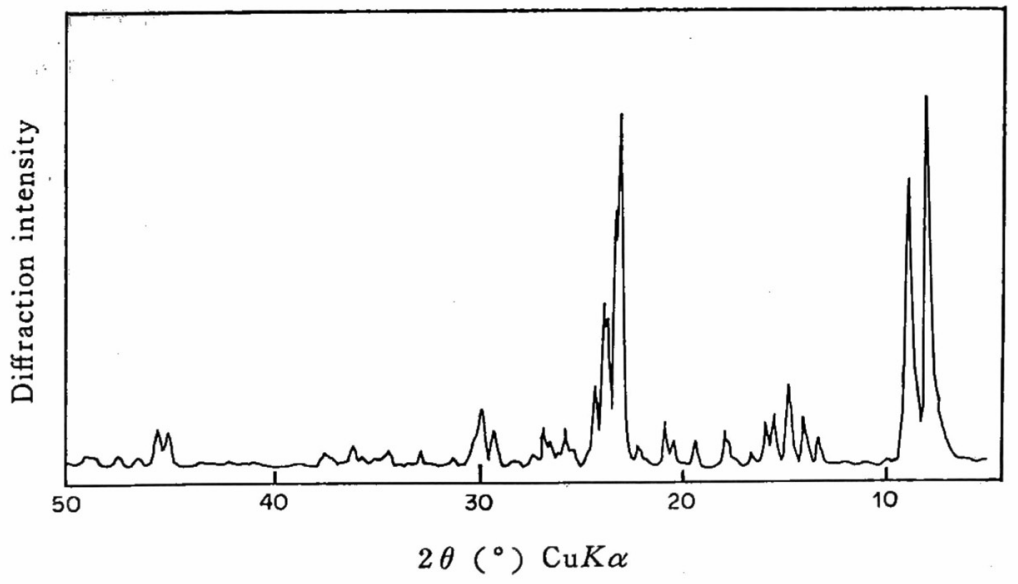

Fig. 2 X-ray diffraction pattern of AEZ-Ca-200 
Table 1 Characteristics of, various zeolites

\begin{tabular}{|c|c|c|c|c|c|c|c|c|c|}
\hline \multirow{2}{*}{ Catalyst ${ }^{a)}$} & \multicolumn{3}{|c|}{$\begin{array}{c}\text { Chemical analysis }{ }^{b)} \\
\text { (molar ratio) }\end{array}$} & \multirow{2}{*}{$\begin{array}{c}\text { BET } \\
\text { surface } \\
\text { area } \\
\left(\mathrm{m}^{2} / \mathrm{g}\right)\end{array}$} & \multirow{2}{*}{$\begin{array}{c}\text { Particle } \\
\text { siz? } \\
(\mu \mathrm{m})\end{array}$} & \multicolumn{3}{|c|}{$\begin{array}{l}\left.\mathrm{NH}_{3} \text { adsorbed }{ }^{c}\right) \\
(\mathrm{m} \mathrm{mol} / \mathrm{g})\end{array}$} & \multirow{2}{*}{$\begin{array}{c}\text { Coket } \\
\text { content } \\
(\text { wt } \%)\end{array}$} \\
\hline & $\mathrm{SiO}_{2} / \mathrm{Al}_{2} \mathrm{O}_{3}$ & $\mathrm{M}^{\prime} \mathrm{O} / \mathrm{SiO}_{2}$ & $\mathrm{M}^{\prime} \mathrm{O} / \mathrm{Al}_{2} \mathrm{O}_{3}$ & & & LTP & HTP & Total & \\
\hline ZSM-5-200 & 210 & 0 & 0 & 360 & $3 \sim 5$ & 0 & 0.164 & 0.164 & 12.8 \\
\hline $\mathrm{AEZ}-\mathrm{Mg}-200$ & 215 & 0.0041 & 0.88 & 351 & $3 \sim 6$ & 0 & 0.156 & 0.156 & 5. 0 \\
\hline $\mathrm{AEZ}-\mathrm{Ca}-200$ & 211 & 0.0153 & 3. 22 & 315 & $3 \sim 6$ & 0.032 & 0.084 & 0.116 & 0.6 \\
\hline $\mathrm{AEZ}-\mathrm{Sr}-200$ & 206 & 0.0176 & 3. 63 & 316 & $3 \sim 8$ & 0.058 & 0.071 & 0.129 & 0.9 \\
\hline $\mathrm{AEZ}-\mathrm{Ba}-200$ & 203 & 0.0141 & 2.86 & 315 & $3 \sim 8$ & 0.054 & 0.034 & 0.088 & 0.4 \\
\hline
\end{tabular}

a) Synthesis conditions: $\mathrm{SiO}_{2} / \mathrm{Al}_{2} \mathrm{O}_{3}=200, \mathrm{OH}^{\prime} / \mathrm{SiO}_{2}=0.1, \quad \mathrm{TPABr} / \mathrm{SiO}_{2}=0.1, \mathrm{H}_{2} \mathrm{O} / \mathrm{SiO}_{2}=40, \mathrm{M}^{\prime} \mathrm{O} / \mathrm{SiO}_{2}=0.025, \quad\left(\mathrm{M}^{\prime}=\right.$ $\mathrm{Mg}, \mathrm{Ca}, \mathrm{Sr}, \mathrm{Ba}), 160^{\circ} \mathrm{C}-18 \mathrm{~h}$.

b) After $\mathrm{H}$ ion exchange by $0.6 \mathrm{~mol} \cdot \mathrm{dm}^{-3} \mathrm{HCl}$.

c) LTP and HTP are the low temperature and high temperature desorption peaks of zeolites, respectively.

(d) After methanol conversion at $400 \sim 600^{\circ} \mathrm{C}$ for $18 \mathrm{~h}$.

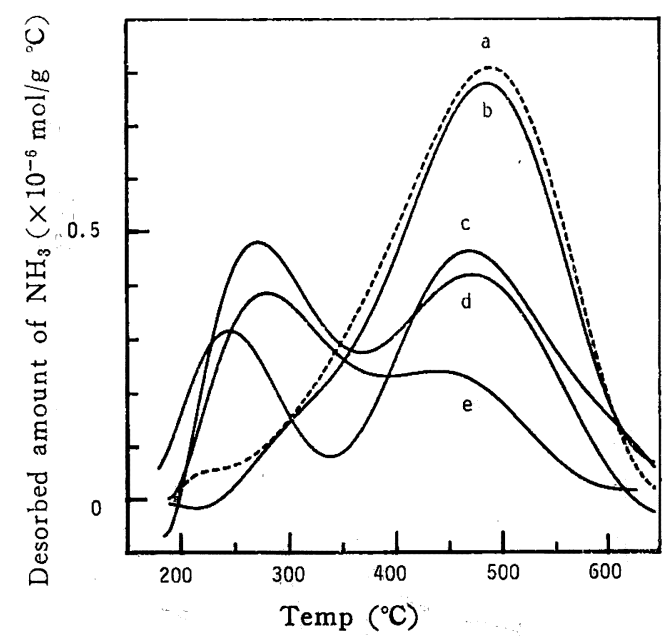

Fig. 3 Temperature-programmed desorption of ammonia from various zeolites

(a) : ZSM-5-200, (b) : AEZ-Mg-200, (c) : AEZ$\mathrm{Ca}-200$, (d):AEZ-Sr-200, (e) : AEZ-Ba-200

$\mathrm{DME}=$ ジメチルエーテル。

\section{3 結果之考察}

\section{1 触媒物性}

用いたゼオライト触媒の仕込み $\mathrm{SiO}_{2} / \mathrm{Al}_{2} \mathrm{O}_{3}$ 比は 200 であり， 合成後の水素イオン交換したゼオライトについての分析值をほか の物性値とともにまとめて表 1 に示す。合成品中の $\mathrm{SiO}_{2} / \mathrm{Al}_{2} \mathrm{O}_{3}$ 比は仕込み比とほぼ同一であったが, アルカり土類金属含有量 $\left(\mathrm{M}^{\prime} \mathrm{O} / \mathrm{SiO}_{2}\right.$ 比）は仕込み比に比較して小さい值であった。しか し, $\mathrm{M}^{\prime} \mathrm{O} / \mathrm{Al}_{2} \mathrm{O}_{3}$ 比化換算すると $\mathrm{AEZ}-\mathrm{Mg}$ では 1 以下であった が， AEZ-Ca, Sr, Ba では1よりもかなり大さい值となった。この ことは，水素イオン交掺後に扣いても，アルカリ土類金属が $\mathrm{Al}$ の近傍のほか， $\mathrm{SiO}^{-}$のような陰イオン性のサイトなど， シリカ 部分にも存在している可能性を示す。すでに, Chester ら5は, ZSM-5 と 11 のうち, 有機塩基を除去した烍成品では, 酸点と然 関係な陰イオン性の紊イトに金属就よび有機陽イオンがイオン交

5) A.W.Chester, Y.F.Chu, R. M. Dessau, G. T. Kerr, C. T. Kresge, J. Chem. Soc., Chem. Commun., 1985, 289.

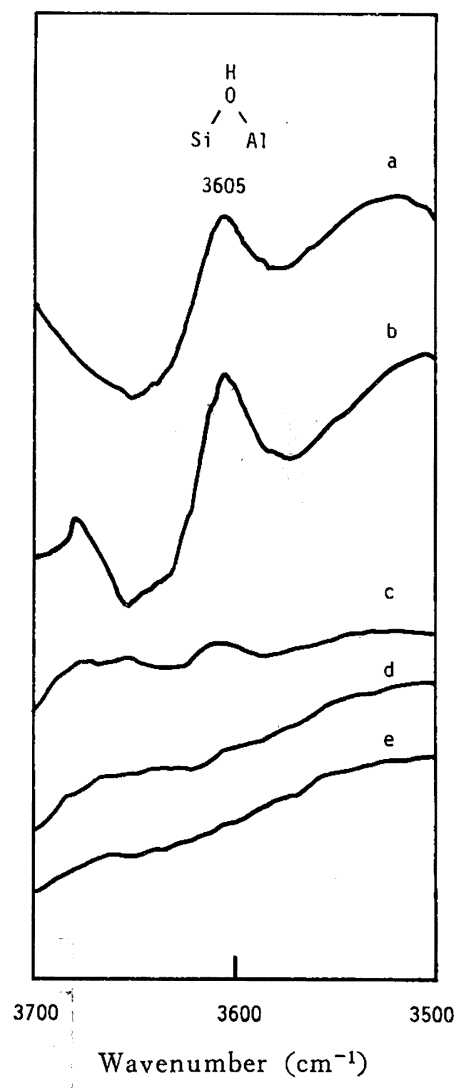

Fig. 4 IR spectra of various zeolites (a) : ZSM-5-200, (b):AEZ-Mg-200, (c):AEZ$\mathrm{Ca}-200$, (d) : $\mathrm{AEZ}-\mathrm{Sr}-200$, (e) $: \mathrm{AEZ}-\mathrm{Ba}-200$

換することを報告して拈り，合成段階でアルカリ土類金属が $\mathrm{SiOH}$ などと反応することは十分にあり得ると考えている。

BET 比表面積は, アルカリ土類金属塩の添加により減少する 傾向がみられた。

図 1 に，各ゼオライト触媒の電子顕微鏡写真を示したが、各ゼ オライトの粒子径はアルカリ上類金属塩の添加により，ZSM-5< $\mathrm{AEZ}-\mathrm{Mg}<\mathrm{AEZ}-\mathrm{Ca}<\mathrm{AEZ}-\mathrm{Sr}<\mathrm{AEZ}-\mathrm{Ba}$ の順にわずかに大き なる傾向がみられた。

図 2 に， AEZ-Ca のX線回折図を示す。AEZ-Ca のX線回折図 以 ZSM-5 と類似して抢り，AEZ-Mg，Sr，Ba も同様であった。 

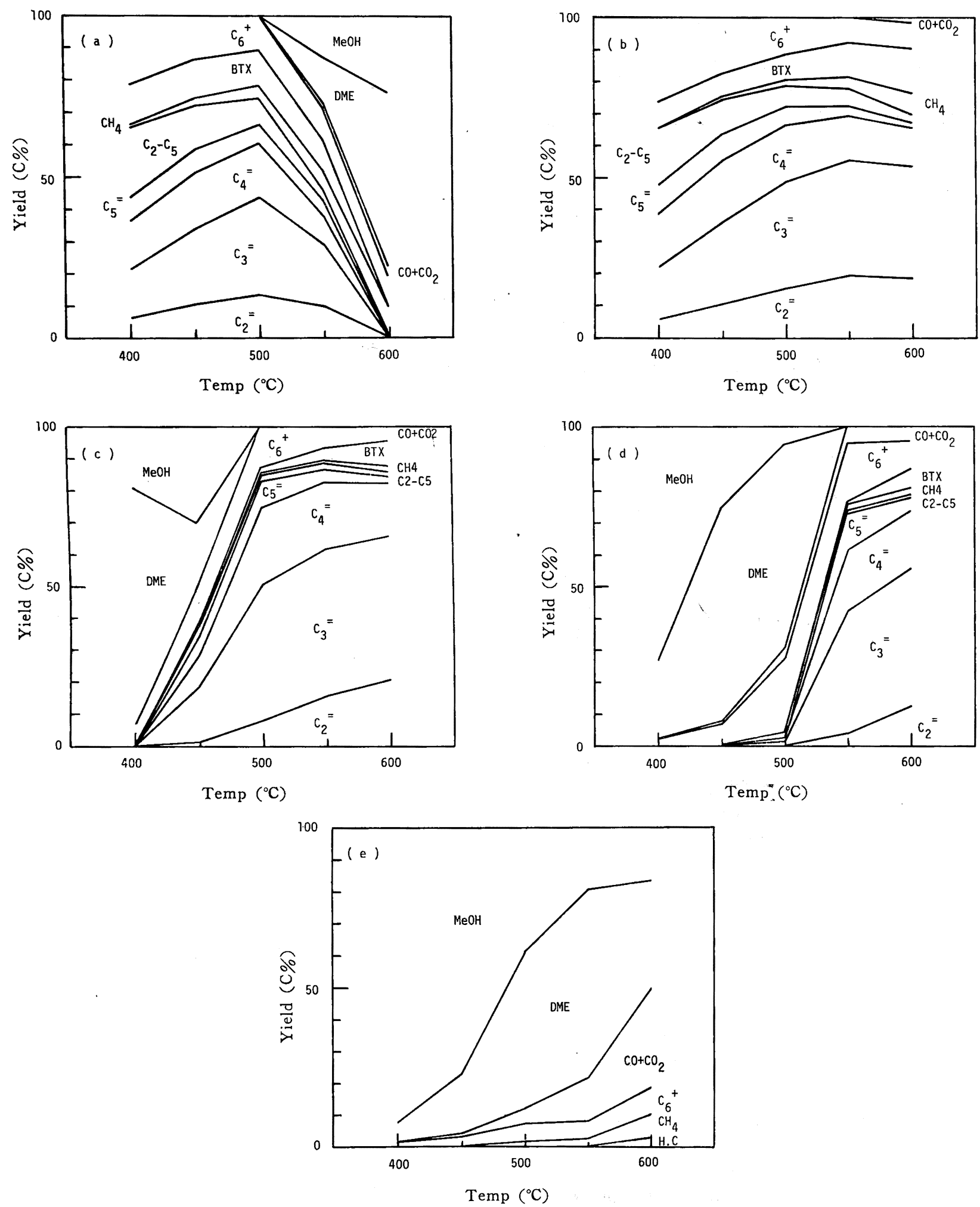

Fig. 5 Methanol conversion to hydrocarbons over various zeolites

(a) : ZSM-5-200, (b ):AEZ-Mg-200, (c ):AEZ-Ca-200, (d):AEZ-Sr-200, (e):AEZ-Ba-200 Reaction conditions : $\mathrm{LHSV}=2.3 \mathrm{~h}^{-1}, \mathrm{Temp}=400 \sim 600^{\circ} \mathrm{C}$ for $18 \mathrm{~h}$

\section{2 酸 性 㯰}

図 3 Kフンモニア昇温脱離曲線 $\left(\mathrm{NH}_{3}-\mathrm{TPD}\right)$ を示したが, $350^{\circ} \mathrm{C}$ を境にして高温侧 (HTP) と低温侧 (LTP) に二つのピー
クが観測された。表 1 に高温側と低温側のピークの測定值を示し たが,これら二つのピークの比率を比較すると，ZSM-5 と AEZ$\mathrm{Mg}$ では同様の比率であり，LTP はきわめて小さく，HTP が主 
であった。それに対して, AEZ-Ca, $\mathrm{Sr}, \mathrm{Ba}$ では $\mathrm{Ca}, \mathrm{Sr}, \mathrm{Ba}$ の順に HTP が娍少し, LTP が増加する㑯向であった。このような酸量 の相違は, 塩基性の異なるアルカリ土類金属で酸点を修䬣したこ とにより生じたものと思われる。さらに, これらのことは, 図 4 に示した FT-IR の測定結果からも理解される。図に怙ける 3605

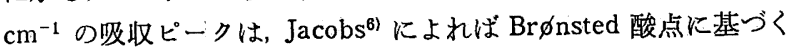
$\mathrm{Si}(\mathrm{OH}) \mathrm{Al}$ の吸収ピークである。このピークについて, ZSM-5 と 比較すると, $\mathrm{AEZ}-\mathrm{Mg}$ では同程度の強度であり， $\mathrm{Mg}$ による酸点 の修飾は見かけ上ほとんど行なわれていないことがわかる。それ に対して，AEZ-Ca, $\mathrm{Sr}, \mathrm{Ba}$ ではいちじるしく減少していた。これ らのことは, $\mathrm{NH}_{3}$-TPD K拈ける強酸量の結果と対応して拈り, $\mathrm{Mg}$ 以外のアルカリ土類金属の㳢加により, 強酸点が弱酸点へ変 化したことを示唆する。

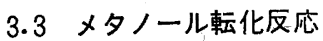

上記のような物性を示すゼオライト触媒について，LHSV = $2.3 \mathrm{~h}^{-1}$ でメタノール転化反応を行ない，アルカリ土類金属の影 幚を調べた。反応は, 通油後 $400^{\circ} \mathrm{C} に 2$ 時間保持したのち,

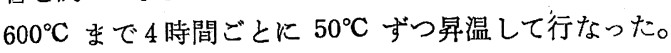

図 5 に, $\mathrm{SiO}_{2} / \mathrm{Al}_{2} \mathrm{O}_{3}$ 比が 200 のアルカリ土類金属含有ゼオラ イトと ZSM-5 触媒の反応結果を示す。有效転化率は反応温度と ともに上䒜し, 有效転化率が $100 \%$ となる温度は, ZSM-5 $\left(400^{\circ} \mathrm{C}\right.$ 以下 $) \approx \mathrm{AEZ}-\mathrm{Mg}\left(400^{\circ} \mathrm{C}\right.$ 以下 $)<\mathrm{AEZ}-\mathrm{Ca}\left(500^{\circ} \mathrm{C}\right)<\mathrm{AEZ}-\mathrm{Sr}(550$ $\left.{ }^{\circ} \mathrm{C}\right)$ の順に高温側に移行し, AEZ-Ba では $600^{\circ} \mathrm{C}$ をで有効転化 率は 100\% に達しなかった。また，有効転化率が 100\% に達し たゼオライト触媒のらち， $\mathrm{AEZ}-\mathrm{Mg}, \mathrm{Ca}, \mathrm{Sr}$ では $600^{\circ} \mathrm{C}$ の高温 領域に括いて子有効転化率が $100 \%$ であり，見かけ上は活性劣化 がみられなかった。それに対し，ZSM-5 では 400〜 500 C で有効 転化率が $100 \%$ であったが，550 $\mathrm{C}$ 以上ではいちじるしい活性劣 化がみられた。また，すでに報告したように2)， $\mathrm{SiO}_{2} / \mathrm{Al}_{2} \mathrm{O}_{3}$ 比が $70 \sim 3300$ の ZSM-5 の場合, $500^{\circ} \mathrm{C}$ 以上の高温の反応条件下では 高シリカ型ほど活性劣化がいちじるしく，高シリカ型にすれば高 温に耐えるといらことはなかった。以上のことは, アルカリ土類 会属含有ゼオライトが高温での低級オンフィン合成用として優れ た触煤であることを示す。また，反応温度と生成物組成の関係を みると, これらのゼオライト触媒の全体の傾向として, 反応温度 の上昇とともに生成物中のエチレン, プロピレン, メタン, B. T. $\mathrm{X}, \mathrm{CO}, \mathrm{CO}_{2}$ が増加し, $\mathrm{C}_{4}{ }^{\prime \prime}, \mathrm{C}_{5}{ }^{\prime \prime}, \mathrm{C}_{2} \sim \mathrm{C}_{5}$ パラフィン, $\mathrm{C}_{6}{ }^{+}$が 诚少する傾向がみられた。

つぎに，高活性なため，5500 以上ではすでに活性が劣化した ZSM-5 を除いて, 各 $\mathrm{AEZ}-\mathrm{M}^{\prime}$ 触䄸の $600^{\circ} \mathrm{C}$ での生成物組成をみ ると, ェチレンとプロピレンの収率は, $\mathrm{AEZ}-\mathrm{Ba}(2 \%) \ll \mathrm{AEZ}-\mathrm{Mg}$ $(54 \%)<\mathrm{AEZ}-\mathrm{Sr}(56 \%)<\mathrm{AEZ}-\mathrm{Ca}(66 \%)$ の順であり, AEZ-Ca で最大であった。さらに， $\mathrm{C}_{4}{ }^{\prime \prime}$ と $\mathrm{C}_{5}{ }^{\prime \prime}$ を加えた $\mathrm{C}_{2} \sim \mathrm{C}_{5}$ オレフィ ンの収率でも AEZ-Ca がもっとも多く $84 \%$ であった。 $\mathrm{C}_{2} \sim \mathrm{C}_{5}$ パラフィンの収率は, 各ゼオライトとも比較的少なく $3 \%$ 以下で

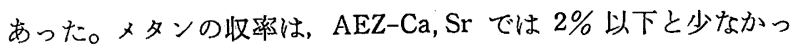
たが, AEZ-Mg, Ba では 7〜9\% であった。B.T.X の収率は, $\mathrm{AEZ}-\mathrm{Mg}$ でもっとも多く $14 \%$ であり, AEZ-Ca, Sr の 2 倍以上 生成した。 $\mathrm{CO}$ と $\mathrm{CO}_{2}$ の収率は, アルカリ土類金属の塩基性の増 大とともに增加し，AEZ-Ba では $31 \%$ ときわめて多く，ほかの ゼオライト触媒の 7 倍以上生成した。

6) P. A. Jacobs, J. Phys. Chem., 86, 3050(1982).

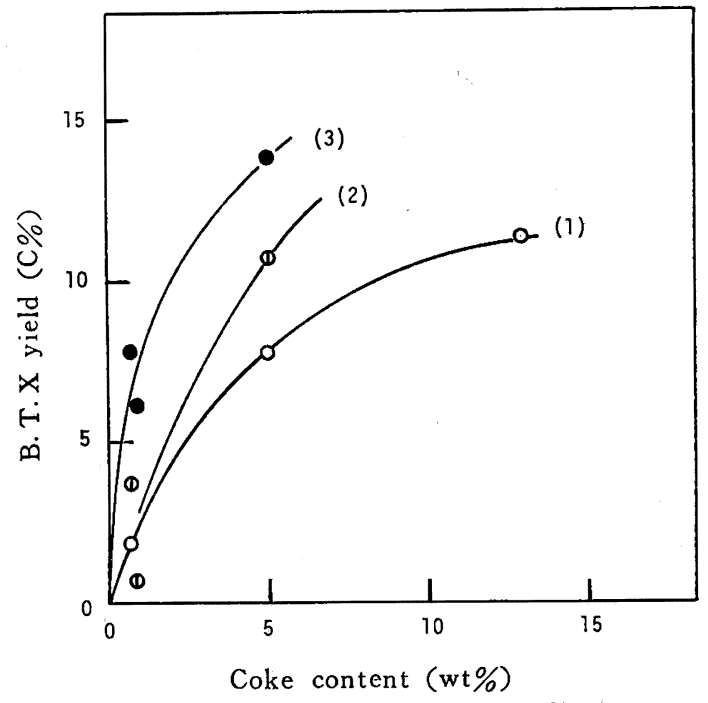

Fig. 6 Relationship between B.T.X yield and coke content

B. T. X yield : (1) $500^{\circ} \mathrm{C}$, (2) $550^{\circ} \mathrm{C}$, (3) $600^{\circ} \mathrm{C}$ Colse content: After methanol conversion at $400 \sim$ $600^{\circ} \mathrm{C}$ for $18 \mathrm{~h}$

これらのことは, 各ゼオライト触媒の酸性質の違いによるもの と思われる。すなわち, アルカリ土類金属の塩基性の増大にとも ない, $\mathrm{AEZ}-\mathrm{Mg}>\mathrm{AEZ}-\mathrm{Ca}>\mathrm{AEZ}-\mathrm{Sr}>\mathrm{AEZ}-\mathrm{Ba}$ の順に酸量と酸 強度が減少した結果, メタノール転化反応活性が低下し, 水素移 行反応による芳香族化反応とパラフィン生成反応もいちじるしく 抑制され，また高温での劣化も起こらなくなった。しかし，同時 に別反応である $\mathrm{CO}$ や $\mathrm{CO}_{2}$ への分解反応性も上記の順に増大す る傾向を示した。結局, これらの相反する傾向が適度に調和した AEZ-Ca の場合に, 高温での低級オンフィン収率がもっとも高く なったものと思われる。

ところで, アルカリ土類金属で Brønsted 強酸点を減少させる ことは, 単に ZSM-5 触媒において高シリカ型にし, 酸量を減少 させることと同一であることも考えられる。しかし、すでに報告 したように2), 高シリカ型 ZSM-5 は, 高シリカ型ほど活性劣化 を受けやすく、アルカリ土類金属含有ゼオライトのよらな高温で 安定な結果は得られなかった。それゆえ、アルカり土類金属によ り酸点を修飾することは，単に Brønsted 強酸点を隇少させるこ とと同一ではなく，酸量と酸強度を低級オレフィン合成に適した よらに調整することに有効であったと考えられる。

\section{4 炭素質量の測定}

反応後の触媒に沈着していた平均の炭素質量を表 1 に示す。炭 素質量は, ZSM-5 (12.8 wt \%) >AEZ-Mg (5.0 wt \%) >AEZ-Sr $(0.9 \mathrm{wt} \%) \approx \mathrm{AEZ}-\mathrm{Ca}(0.6 \mathrm{wt} \%) \approx \mathrm{AEZ}-\mathrm{Ba}(0.4 \mathrm{wt} \%)$ の順に減 少した。また，反応後の触媒の外観をみると，ZSM-5 では触媒層 全体が黑色に変色していたが，AEZ-Mgでは上層部のみが黑色 で, 下層部は淡い灰色であり，AEZ-Ca， $\mathrm{Sr}, \mathrm{Ba}$ では上層部のほ んのわずかが黒色に変色していた。なお， $\mathrm{AEZ-Mg} \mathrm{について上}$ 層部と下層部に分けて炭素質量を測定したが，上層部では 13.8 $\mathrm{wt} \%$ ，下層部では $0.8 \mathrm{wt} \%$ であった。このことは，炭素質生成 が反応時間とともに触煤上層部から下層部へ進行することを示 し，AEZ-Mg では ZSM-5 にくらべて炭素質生成速度が遅くな 
っていることを示す。

また，因6に各ゼオライト触㷊について，500〜 $600^{\circ} \mathrm{C}$ の各反応 温度に拈ける B. T.X 収率と反応後の炭素筫卧との関係を示す。 ここで，B.T.X 収率は有効転化率が 100\% 時の值を用いた。四 から， B.T.X 収染と炭慗舅には相関がみとめられることがわ かり， B. T. X は炭素質生成の中間体の一つと溚えられる。それ ゆえ，アルカリ土類金属含有ぜオライトでは，アルカリ土類金属 の添加により酸強度が弱くなったため, B. T.X 生成が娍少し, その絬果炭菜塤量が減少したものと思われる。

一方、寸でに報告したよ $5 K^{2)}, \mathrm{SiO}_{2} / \mathrm{Al}_{2} \mathrm{O}_{8}$ 比が $70 \sim 3300$ の ZSM-5 では，本研究と同一区応采件下での炭素留は 16.7 $4.2 \mathrm{wt} \%$ であり，高シリカ型になるほど減少したが，炭化水素へ の転化反応活性をほとんど示さない $\mathrm{SiO}_{2} / \mathrm{Al}_{2} \mathrm{O}_{3}$ 比が 3300 の
ZSM-5 でさえも，岸惄質量は $4.2 \mathrm{wt} \%$ であることを示した。 それに対し，アルカリ上類金属含有ゼオライトのうち， AEZ-Ca, $\mathrm{Sr}, \mathrm{Ba}$ では，炭素啠量は 1 wt％ 以下であり，高シリカ型 ZSM5 に比校してさわめて炭素質量が少ないことがわかる。

本研究では $400^{\circ} \mathrm{C}$ 以上の高温条件下で反応させ，炭絜質の生成

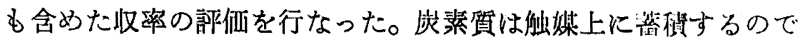

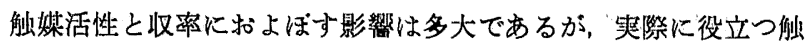
媒性能は被斑後の見かけの性能である。このよらな観点から、ア ルカリ土類金属含有ゼオライトは低級オレフィン合成雨高温能媒 として，優れた性能を有することが明らかとなった。

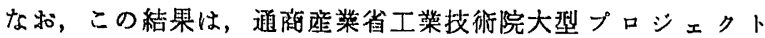
「シーワン化学」の研究成果である。

\title{
The Conversion of Methanol into Light Olefins on Zeolites Containing Alkaline Earth Metals
}

\author{
Hideo OKado*, Hiroshi Shojt, Kichinari Kawamura**, \\ Yasuhiko Koнtoru***, Yasuyoshi Yamazaki****, \\ Tuneji SANO***** and Haruo TAKAYA***** \\ Maruzen Petrochemical Co., Ltd.; Hatchobori, Chuo-ku, Tokyo 104 Japan \\ ** Idemitsu Petrochemical Co., Ltd.; Marunouchi, Chiyoda-ku, Tokyo 100 Japan \\ *** Ube Industries Co., Ltd.; Kasumigaseki, Chiyoda-ku, Tokyo 100 Japan \\ **** Nippon Petrochemical Co., Ltd.; Uchisaizeai-cho, Chiyoka-ku, Tokyo 100 Japan \\ ***** National Chemical Laboratory for Industry; Yatabe, Tukuba, Ibaraki 305 Japan
}

As the catalyst for synthesis of light olefins from methanol, zeolites containing alkaline earth metals (AEZ) were synthesized. The AEZ- $\mathrm{M}^{\prime}-200\left(\mathrm{M}^{\prime}=\right.$ alkaline earth metal, $200=$ $\mathrm{SiO}_{2} / \mathrm{Al}_{2} \mathrm{O}_{3}$ ratio) was synthesized by a hydrothermal method with a gel mixture from $\left(\mathrm{Na}_{2} \mathrm{O}\right.$, $\mathrm{M}^{\prime} \mathrm{O}$ )-(TPA) ${ }_{2} \mathrm{O}-\mathrm{Al}_{2} \mathrm{O}_{3}-\mathrm{SiO}_{2}-\mathrm{H}_{2} \mathrm{O}$ system, where a source of $\mathrm{M}^{\prime} \mathrm{O}$ was alkaline earth metal acetate such as $\mathrm{Mg}, \mathrm{Ca}, \mathrm{Sr}$ and $\mathrm{Ba}$. The catalyst activity of methanol conversion into light olefins was studied on the AEZ-M' in compared with the ZSM-5.

The reaction was carried out using an atmospheric pressure fixed bed flow reactor at LHSV= $2.3 \mathrm{~h}^{-1}$ from 400 to $600^{\circ} \mathrm{C}$. From these results, the high catalyst activity and the high yield of ethylene and propylene were demonstrated on AEZ-Mg, Ca and Sr. The maximum yield of ethylene and propylene was $66 \%$ on the AEZ-Ca. On the ZSM-5, the deactivation was observed at high temperature. On AEZ-Ba, light olefins were hardly produced.

These zeolites were characterized by determining BET surface area, the particle size by SEM, and the acid property by the methods of $\mathrm{NH}_{3}-\mathrm{TPD}$ and FT-IR, and X-ray diffraction (Table 1). Coke contents of these catalysts were measured after the reaction. The AEZ$\mathrm{M}^{\prime}$ showed the comparatively smaller coke content. From these physicochemical measurements, it was indicated that on the AEZ- $\mathrm{M}^{\prime}$, not only the amount of strong acid decreased, but also the acid strength became weak. It seemed that the high selectivity to light olefins was demonstrated on the AEZ-M' by the minimization of B. T. X, paraffins and coke products. 